Article

\title{
Enhancer of Zeste Homolog 2 (EZH2) Mediates Glucolipotoxicity-Induced Apoptosis in $\beta$-Cells
}

\author{
Tina Dahlby ${ }^{1}$, Christian Simon ${ }^{2}{ }^{\oplus}$, Marie Balslev Backe ${ }^{1}$, Mattias Salling Dahllöf ${ }^{1}$, \\ Edward Holson ${ }^{3}$, Bridget K. Wagner ${ }^{3}$, Marianne Böni-Schnetzler ${ }^{4}{ }^{\circledR}$, Michal Tomasz Marzec ${ }^{1} \mathbb{D}$, \\ Morten Lundh 1,3 (D) and Thomas Mandrup-Poulsen ${ }^{1, *(D)}$ \\ 1 Department of Biomedical Sciences, University of Copenhagen, DK-2200 Copenhagen, Denmark; \\ tinad@sund.ku.dk (T.D.); mariebacke8@gmail.com (M.B.B.); mattiassd@gmail.com (M.S.D.); \\ michal@sund.ku.dk (M.T.M.); lundh@sund.ku.dk (M.L.) \\ 2 Novo Nordisk Foundation Center for Protein Research, University of Copenhagen, \\ DK-2200 Copenhagen, Denmark; christian.simon@cpr.ku.dk \\ 3 Broad Institute of MIT and Harvard, Cambridge, MA 02142, USA; eholson@kdactherapeutics.com (E.H.); \\ bwagner@broadinstitute.org (B.K.W.) \\ 4 Department of Biomedicine, University Hospital and University of Basel, 4031 Basel, Switzerland; \\ marianne.boeni@unibas.ch \\ * Correspondence: tmpo@sund.ku.dk; Tel.: +45-30-33-03-87
}

Received: 28 September 2020; Accepted: 26 October 2020; Published: 29 October 2020

\begin{abstract}
Selective inhibition of histone deacetylase 3 (HDAC3) prevents glucolipotoxicity-induced $\beta$-cell dysfunction and apoptosis by alleviation of proapoptotic endoplasmic reticulum (ER) stress-signaling, but the precise molecular mechanisms of alleviation are unexplored. By unbiased microarray analysis of the $\beta$-cell gene expression profile of insulin-producing cells exposed to glucolipotoxicity in the presence or absence of a selective HDAC3 inhibitor, we identified Enhancer of zeste homolog 2 (EZH2) as the sole target candidate. $\beta$-Cells were protected against glucolipotoxicity-induced ER stress and apoptosis by EZH2 attenuation. Small molecule inhibitors of EZH2 histone methyltransferase activity rescued human islets from glucolipotoxicity-induced apoptosis. Moreover, EZH2 knockdown cells were protected against glucolipotoxicity-induced downregulation of the protective non-canonical Nuclear factor of kappa light polypeptide gene enhancer in B-cells (NFKB) pathway. We conclude that EZH2 deficiency protects from glucolipotoxicity-induced ER stress, apoptosis and downregulation of the non-canonical NFKB pathway, but not from insulin secretory dysfunction. The mechanism likely involves transcriptional regulation via EZH2 functioning as a methyltransferase and/or as a methylation-dependent transcription factor.
\end{abstract}

Keywords: GLT; histone deacetylases; histone methyltransferase; diabetes; insulin secretion; ER stress; NFKB

\section{Introduction}

Type 2 diabetes (T2D) arises when pancreatic $\beta$-cell insulin secretion fails to meet insulin demands, which increase due to insulin resistance secondary to obesity [1]. The predisposition to develop T2D is polygenetic and conferred by combinations of multiple genetic variants mainly encoding $\beta$-cell regulatory proteins. Environmental factors such as overnutrition and inadequate physical activity significantly contribute to T2D etiology by shifting the energy-balance towards caloric storage and obesity, and by affecting gene transcription by epigenetic mechanisms [2].

Nutrient overload causes $\beta$-cell impairment via toxic effects of elevated blood saturated non-esterified fatty acids (NEFAs) and glucose, termed glucolipotoxicity (GLT). NEFAs induce apoptosis [3,4] and inhibit glucose-stimulated insulin-secretion (GSIS) $[4,5]$ in $\beta$-cell lines and rat 
and human islets in vitro. Elevated concentrations of NEFAs infused in humans cause impaired $\beta$-cell function [6,7]. Likewise, elevated concentrations of glucose reduce $\beta$-cell function in vivo [8], and reduce GSIS, insulin content and insulin gene expression and induce apoptosis in vitro $[3,9,10]$, and exposure of $\beta$-cell lines to the NEFA palmitate alters gene expression and histone marks in parallel to impairing insulin secretion [11].

Histone deacetylases (HDACs) catalyze the removal of acetyl groups from lysine residues in histone tails and in $>4500$ cytosolic proteins, including transcription factors [12]. In the pancreatic $\beta$-cell, HDACs 1 and 3 in particular mediate functional impairment and apoptosis in response to inflammatory and glucolipotoxic stress [13-20]. Pan-HDAC and HDAC1- and 3-selective small-molecule HDAC-inhibitors (HDACi) prevent inflammation-induced $\beta$-cell dysfunction and apoptosis in cell- and animal-models of diabetes [14,18-20] by hyperacetylation, and thereby inactivation, of the master proinflammatory transcription factor Nuclear factor of kappa light polypeptide gene enhancer in B-cells (NFKB) p65 subunit [20].

Additionally, HDACi prevent GLT-induced $\beta$-cell apoptosis in vitro and in vivo [15-17]. In GLT-exposed $\beta$-cells, selective histone deacetylase 3 inhibition (HDAC3i) alleviates proapoptotic endoplasmic reticulum (ER) stress as evidenced by reduced C/EBP homologous protein (Chop) and c-Jun N-terminal kinase (JNK) activation [16], but the precise molecular mechanisms are unknown. Thus, the aim of the current study was to identify such novel targets and mechanisms by which $\beta$-cell dysfunction and apoptosis are reverted by HDAC3i by employing in silico and in vitro models. We identified the histone-lysine $N$-methyltransferase (HMT) Enhancer of zeste homolog 2 (EZH2) as the sole target candidate protein associated with genes regulated by both GLT and HDAC3i in the $\beta$-cell line INS-1E.

EZH2 displays multifaceted functions in cells. The canonical role of EZH2 is co-factor dependent transcriptional repression through three sequential methylations on lysine 27 of the histone-3 tail (H3K27me3) (reviewed in [21]). The core co-factors Suppressor of Zeste 12 (SUZ12), Embryonic Ectoderm Development (EED) and Histone-Binding Protein Histone-Binding Protein Retinoblastoma-Binding Protein 4 (RbAp48) assemble with EZH2 into the Polycomb Repressive Complex 2 (PRC2). The non-canonical roles of EZH2 include protein regulation through PRC2-subunit independent protein-methylation [22,23], and PRC2-independent and methylation-dependent [24,25] or -independent [26] EZH2 transcriptional activation. Intriguingly, EZH2 is a co-activator of the HDAC-regulated transcription factor NFKB [26]. Canonical NFKB activation has been shown to shift the ER stress response from a protective to a proapoptotic mode $[27,28]$, whereas the Chop promoter contains binding sites for the non-canonical NFkB-subunit p52, although it is unknown whether these sites are inhibitory or activating in $\beta$-cells [29].

The current available research on the role of EZH2 in the $\beta$-cell describes EZH2 as a critical regulator of H3K27me3 marks during pancreatic endocrine specification [30], control of $\beta$-cell dedifferentiation $[31,32]$ and as a regulator of $\beta$-cell proliferation $[32,33]$. While homozygous, $\beta$-cell specific EZH2 deficiency in RIP-Cre;Ezh $2^{f f f}$ or $P d x 1-C r e ; E z h 2^{f f f}$ mice induces mild glucose-intolerance and reduced $\beta$-cell mass [30,33]; heterozygous $P d x 1$-Cre;Ezh2 $2^{f /+}$ mice display increased $\beta$-cell mass [30]. In addition, $\beta$ cells of pancreatic sections from human T2D donors exhibit reduced H3K27me3 marks [31]. Interpretation of these findings is difficult, since the outcomes in absence of inducible deletion may be confounded by actions on $\beta$-cell ontogeny, and the changes observed in the human T2D donors can be construed as both pathogenic and defensive.

We here demonstrate a direct protective role of EZH2 deficiency in insulin producing INS-1E cells and in human islets. First, we demonstrate that knockdown or inhibition of EZH2 protects INS-1E cells and human islets against metabolic (GLT-induced) ER stress and apoptosis, without affecting GLT-induced insulin-secretory dysfunction. We provide mechanistic evidence that EZH2 deficiency protects against GLT-induced downregulation of the non-canonical NFKB pathway. 


\section{Results}

\subsection{EZH2 Is a Transcriptional Node Controlling Genes Regulated by GLT and HDAC3 Inhibition}

To investigate the protective mechanisms of HDAC3i in vitro, insulin producing INS-1E cells were exposed to GLT in the presence or absence of the selective HDAC3i BRD3308 for $6 \mathrm{~h}$. We then performed an explorative mRNA microarray to analyze GLT-regulated mRNAs that were affected by the selective HDAC3i. Microarray data were analyzed by an unbiased bioinformatics analysis, avoiding functional enrichment/pathway analyses, to identify relevant gene sets. Fifty-two genes were differentially regulated by both GLT alone and GLT in combination with BRD3308 (Figure 1A and Table S1). In order to link microarray data to relevant transcription factors targeting the 52 differentially regulated genes in our dataset, we used these genes as input for the in silico ENCODE ChIP-Seq Significance Tool [34]. The Tool only produced one single output: Enhancer of zeste homolog 2 (EZH2). EZH2 is a transcription factor and was associated with 22 of 49 genes in our list (Figure 1B), suggesting that EZH2 regulates these genes Three rat-specific genes, Aminopeptidase O (Npepo), Interferon, alpha-inducible protein 27 like $2 B$ (Ifi27l2b) and Similar to alpha-fetoprotein (LOC360919) were lost in the analysis, since the Tool employs a human database. However, substituting the rat-specific genes with their human counterparts, Aopep, Ifi27l2 and Afp, respectively, did not change the analysis. The microarray was validated by qPCR of selected genes (Figure S1A-F), and we confirmed that GLT and BRD3308 regulate apoptosis in our cell model (Figure S2).

\subsection{EZH2 Attenuation Protects Against GLT-Induced Apoptosis}

Since the function of EZH2 in GLT-exposed $\beta$-cells is unknown, we investigated the effect of EZH2 attenuation on GLT-induced $\beta$-cell apoptosis. For this purpose, we generated stable EZH2 knockdown (KD) INS-1E cell lines using three different shRNAs (sh), achieving 73\% mRNA knockdown with sh1 and $\sim 56 \%$ knockdown with sh3 and sh4 (Figure $2 \mathrm{~A}$ ). These mRNA reductions led to reductions of EZH2 protein levels (Figure 2B). Next, we observed that sh3 and sh4 EZH2 KD cell lines were protected against GLT-induced apoptosis (Figure 2C). In contrast, we observed aggravated GLT-induced apoptosis using sh1 (Figure 2C). To substantiate the contrasting effects of the shRNA-induced EZH2 knockdown, we generated a heterozygous EZH2 expressing cell line (EZH2 HET) using CRISPR/Cas9 and a gRNA targeting the binding-site of the EZH2 co-factor EED required for PRC2-mediated transcriptional repression [21]. This induced a TT insertion on one EZH2-allele (Figure S3A), resulting in a premature stop-codon (Figure S3B) and a $\sim 26 \%$ reduction in mRNA expression (Figure 2D). Similar to sh3- and sh4-expressing cell lines, EZH2 HET was protected against GLT-induced apoptosis (Figure 2E).

Interestingly, we did not observe a reduction in $\beta$-cell growth rate in EZH2 KD or HET cells (Figure S3C,D), as described in homozygous EZH2 knockout mice [30,33]. On the contrary, moderate EZH2 attenuation tended to have an accelerated growth rate (Figure S3C,D).

Finally, we investigated if two different small-molecule inhibitors of EZH2 HMT activity (EZH2i) rescued human islets from GLT-induced $\beta$-cell apoptosis. Since EZH2i induce apoptosis at high concentration in other cell types [35,36], we first tested different concentrations of the EZH2i GSK126 and GSK343 to assess inhibitor toxicity (Figure S4). We observed that $10 \mu \mathrm{mol} / \mathrm{L} \mathrm{EZH2i} \mathrm{induced}$ apoptosis in human islets (Figure S4). Next, we exposed human islets to GLT and observed induction of apoptosis as expected (Figure 2F). When exposing human islets to GLT in combination with low concentrations of either EZH2i, however, we did not observe such an increase in apoptosis (Figure 2F). Taken together, these results suggest that moderate loss of EZH2 HMT-activity protects the $\beta$-cell against GLT-induced apoptosis. 
A
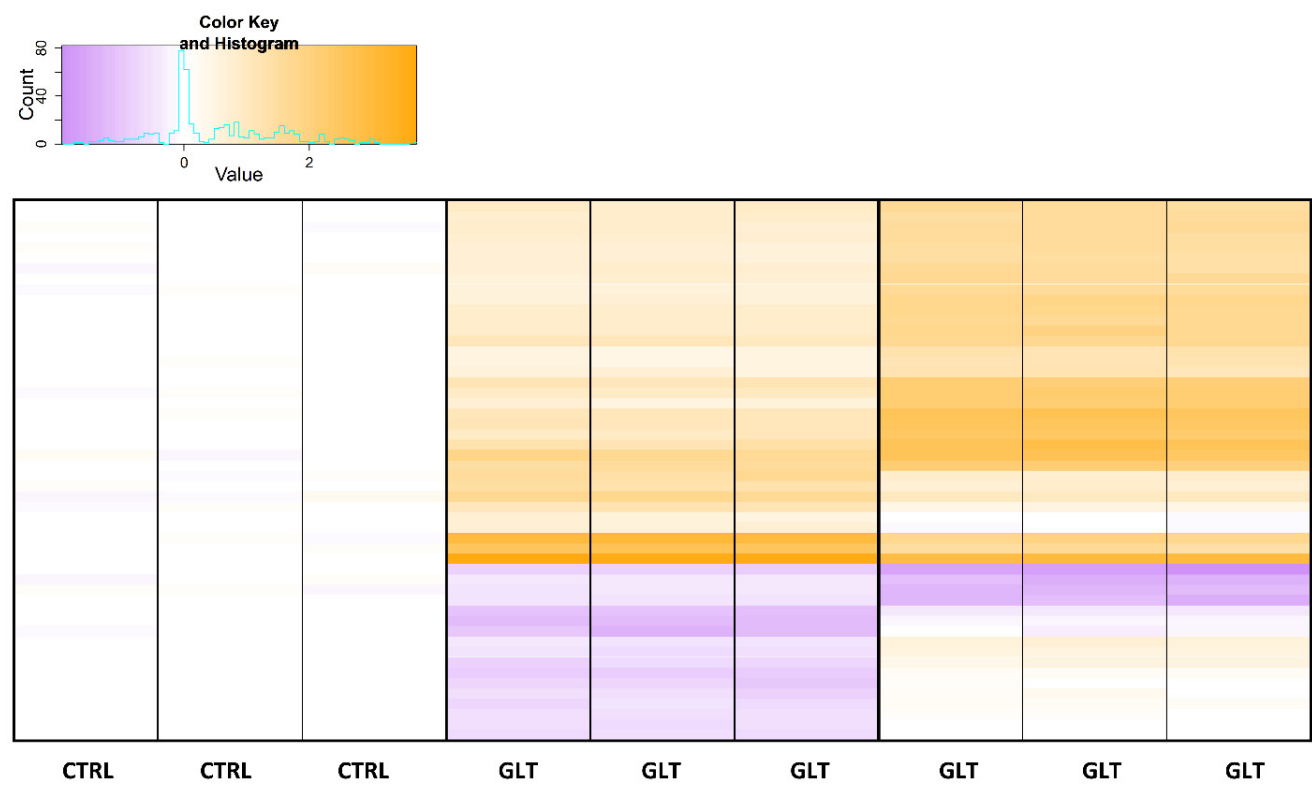

CTRL

CTRL

GLT

GLT

GLT

B

\begin{tabular}{|c|c|c|c|c|c|c|}
\hline Factor & $\begin{array}{l}\text { Total Genes } \\
\text { with Factor }\end{array}$ & \multicolumn{2}{|c|}{$\begin{array}{l}\text { List1 Observed } \\
\text { Genes ( } 49 \\
\text { Total) }\end{array}$} & \multicolumn{2}{|c|}{$\begin{array}{l}\text { List1 Q-value } \\
\text { (Hypergeometric Test; } \\
\text { Benjamini-Hochberg) }\end{array}$} & \multirow[t]{2}{*}{$\begin{array}{l}\text { List1 } \\
\text { Factor } \\
\text { Rank } \\
1\end{array}$} \\
\hline Ezh2 & 3598 & & 22 & & $1.67 \times 10^{-4}$ & \\
\hline $\begin{array}{l}\text { Observed } \\
\text { Symbols for } \\
\text { Ezh2 in } \\
\text { List1 }\end{array}$ & Ensembl IDs & $\begin{array}{l}\text { Entrez } \\
\text { IDs }\end{array}$ & HAVA & IA IDs & Symbols & Description \\
\hline ADORA2B & ENSG00000170425 & 136 & OTTHL & MG00000059140 & ADORA2B & adenosine $\mathrm{A} 2 \mathrm{~b}$ receptor \\
\hline CYS1 & ENSG00000205795 & 192668 & OTTHL & MG00000151703 & CYS1 & cystin 1 \\
\hline FGFR4 & ENSG00000160867 & 2264 & OTTHL & MG00000151523 & FGFR4 & fibroblast growth factor receptor 4 \\
\hline FOS & ENSG00000170345 & 2353 & OTTHL & MG00000171774 & FOS & FBJ murine osteosarcoma viral oncogene homolog \\
\hline FST & ENSG00000134363 & 10468 & OTTHL & MG00000131183 & FST & follistatin \\
\hline HBEGF & ENSG00000113070 & 1839 & OTTHL & MG00000129496 & HBEGF & heparin-binding EGF-like growth factor \\
\hline ID1 & ENSG00000125968 & 3397 & OTTHL & MG00000032181 & ID1 & inhibitor of DNA binding 1, dominant negative helix-loop-helix protein \\
\hline IL15 & ENSG00000164136 & 3600 & OTTHL & MG00000133418 & IL15 & interleukin 15 \\
\hline MSI2 & ENSG00000153944 & 124540 & OTTHL & MG00000178398 & MSI2 & musashi homolog 2 (Drosophila) \\
\hline NGFR & ENSG00000064300 & 4804 & OTTHL & MG00000161495 & NGFR & nerve growth factor receptor \\
\hline NR4A2 & ENSG00000153234 & 4929 & OTTHL & MG00000131950 & NR4A2 & nuclear receptor subfamily 4, group A, member 2 \\
\hline NR4A3 & ENSG00000119508 & 8013 & OTTHL & MG00000021030 & NR4A3 & nuclear receptor subfamily 4, group A, member 3 \\
\hline PRKAG2 & ENSG00000106617 & 51422 & OTTHL & MG00000157324 & PRKAG2 & protein kinase, AMP-activated, gamma 2 non-catalytic subunit \\
\hline PROK2 & ENSG00000163421 & 60675 & OTTHL & MG00000158809 & PROK2 & prokineticin 2 \\
\hline RAP1GAP2 & ENSG00000132359 & 23108 & OTTHL & MG00000177642 & RAP1GAP2 & RAP1 GTPase activating protein 2 \\
\hline RASD1 & ENSG00000108551 & 51655 & OTTHL & MG00000059292 & RASD1 & RAS, dexamethasone-induced 1 \\
\hline REM2 & ENSG00000139890 & 161253 & OTTHL & MG00000170277 & REM2 & RAS (RAD and GEM)-like GTP binding 2 \\
\hline SGK1 & ENSG00000118515 & 6446 & OTTHL & MG00000015613 & SGK1 & serum/glucocorticoid regulated kinase 1 \\
\hline SOX4 & ENSG00000124766 & 6659 & OTTHL & MG00000016101 & SOX4 & SRY (sex determining region Y)-box 4 \\
\hline TNFRSF11B & ENSG00000164761 & 4982 & OTTHL & MG00000164969 & TNFRSF11B & tumor necrosis factor receptor superfamily, member $11 \mathrm{~b}$ \\
\hline TRIM72 & ENSG00000177238 & 493829 & OTTHL & MG00000176754 & TRIM72 & tripartite motif containing 72 \\
\hline VAV3 & ENSG00000134215 & 10451 & OTTHL & MG00000010995 & VAV3 & vav 3 guanine nucleotide exchange factor \\
\hline
\end{tabular}

Figure 1. Enhancer of zeste homolog 2 (EZH2) putatively binds gene targets regulated by glucolipotoxicity (GLT) and BRD3308. (A) mRNA isolated from INS-1E cells exposed to $25 \mathrm{mmol} / \mathrm{L}$ glucose and $0.5 \mathrm{mmol} / \mathrm{L}$ palmitate (GLT) with or without $10 \mu \mathrm{mol} / \mathrm{L}$ histone deacetylase 3 (HDAC3) inhibitor BRD3308 was spotted in triplicate onto an Affymetrix gene array chip ( $n=1$ array). On the heatmap, yellow represent upregulated genes and purple represents downregulated genes relative to the control, with the scale shown in the upper left corner. (A) shows the expression pattern of the 52 genes identified as regulated both by GLT and by BRD3308. See gene names and regulation patterns in Table S1. (B) Genes from (A) were analyzed by the ENCODE ChIP-Seq Significance Tool, and only EZH2 was identified as a factor binding 22 of the genes (top panel). The bottom panel shows a description of the subset of genes from (A) that was identified to contain EZH2 binding sites. The Tool employs a hypergeometric test with multiple hypothesis correcting using Benjamini-Hochberg to calculate binding significance. List1: Input list of the 52 genes from (A). 
A

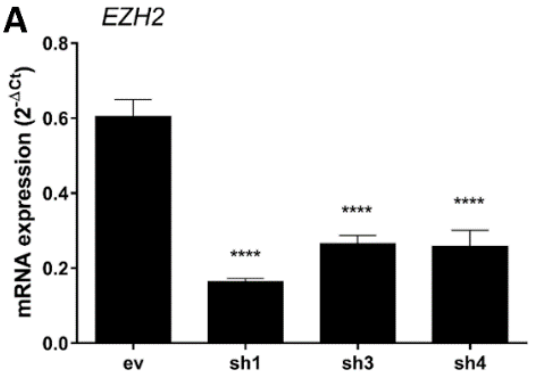

B
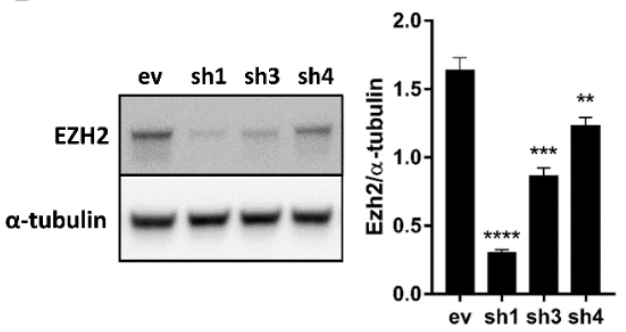

C

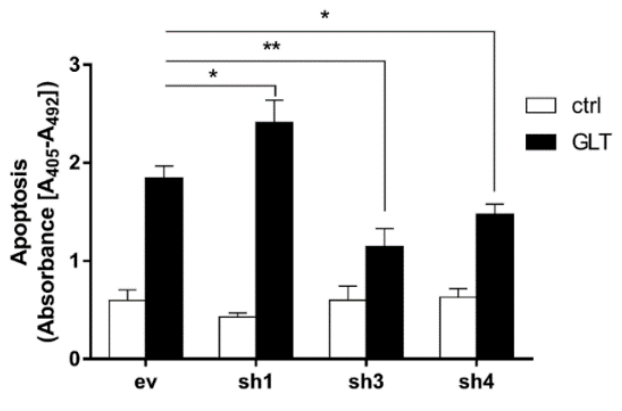

D

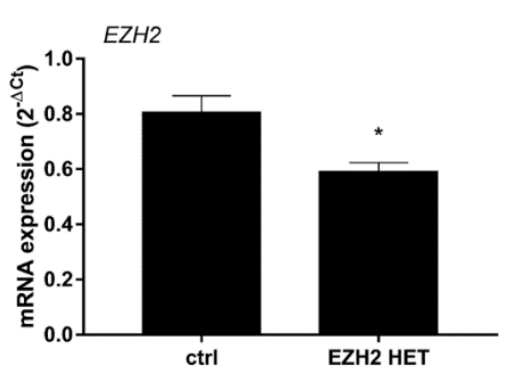

E

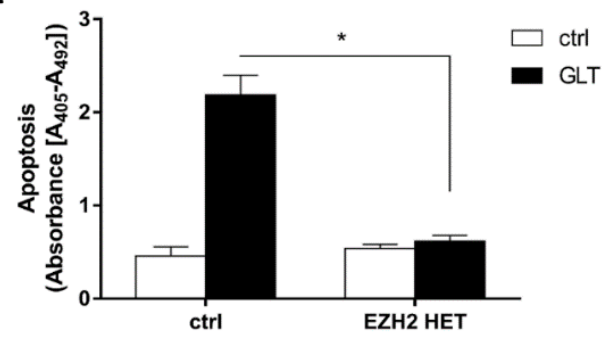

$\mathbf{F}$

$\square$ Vehicle

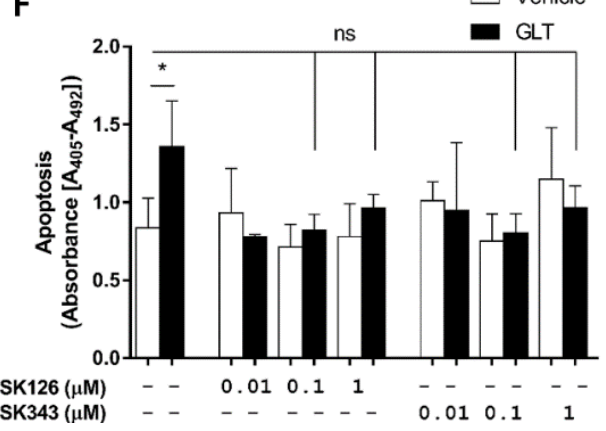

Figure 2. Moderate Enhancer of zeste homolog 2 (EZH2) attenuation protects against glucolipotoxicity (GLT)-induced apoptosis. (A) mRNA expression of $E z h 2$ was measured by real-time quantitative PCR in INS-1E cells expressing different shRNAs targeting EZH2 (EZH2 KDs; sh1, -3 and -4). Data presented as means + SEM of $n=4$, analyzed by one-way ANOVA with Sidak's multiple comparisons test (KDs vs. ev). For (A-C): ev, INS-1E cells transfected with empty vector; sh1, INS-1E cells transfected with shRNA sequence \#1; sh3, INS-1E cells transfected with shRNA sequence \#3; sh4, INS-1E cells transfected with shRNA sequence \#4. (B) EZH2 protein expression was detected by Western blot in EZH2 KDs sh1, -3 and -4 . Representative blot of $n=10$. Data presented as means + SEM of $n=10$, analyzed by one-way ANOVA with Sidak's multiple comparisons test (KDs vs. ev). (C) Fifty-thousand EZH2 KDs sh1, -3 and -4 were exposed to $25 \mathrm{mmol} / \mathrm{L}$ glucose and $0.5 \mathrm{mmol} / \mathrm{L}$ palmitate (GLT) for $24 \mathrm{~h}$. Apoptosis was detected as cytoplasmic accumulation of mono- and oligonucleosomes. Data presented as means + SEM of $n=5-7$, analyzed by one-way ANOVA with Sidak's multiple comparisons test. (D) mRNA expression of Ezh2 was measured by real-time quantitative PCR in INS-1E cells expressing a gRNA targeting exon 3 of EZH2 (EZH2 HET). Data presented as means + SEM of $n=3$, analyzed by paired Student's $t$-test. For (D,E): ctrl, failed INS-1E CRISPR clone; EZH2 HET, CRISPR/Cas9 modified INS-1E with gRNA targeting EZH2 exon 3. (E) Fifty-thousand EZH2 HET cells were exposed to $25 \mathrm{mmol} / \mathrm{L}$ glucose and $0.5 \mathrm{mmol} / \mathrm{L}$ palmitate (GLT) for $24 \mathrm{~h}$. Apoptosis was detected as above. Data presented as means + SEM of $n=4$, analyzed by one-way ANOVA with Sidak's multiple comparisons test. (F) Twenty-five human islets in duplicate were exposed to $25 \mathrm{mmol} / \mathrm{L}$ glucose and $0.5 \mathrm{mmol} / \mathrm{L}$ palmitate (GLT) in the presence or absence of $0.01 \mu \mathrm{mol} / \mathrm{L}(n=2)$ and $0.1-1 \mu \mathrm{mol} / \mathrm{L}(n=5)$ EZH2 inhibitor GSK126 or GSK343 for $72 \mathrm{~h}$. Apoptosis measured as above. Data presented as means + SEM of $n=2-5$, analyzed by one-way ANOVA with post hoc $t$-test. Islet donors: $1,2,3,5,7$ (Table S2). ns: not significant; ${ }^{*} p<0.05$; ${ }^{* *} p<0.01$; ${ }^{* * *} p<0.001$; $* * * * p<0.0001$. 


\subsection{EZH2 Attenuation Protects the $\beta$-Cell against GLT-Induced ER Stress}

While GLT potently induces $\beta$-cell apoptosis after $24 \mathrm{~h}$ exposure, mRNA expression of ER stress markers is induced by GLT as early as $3 \mathrm{~h}$ post exposure [16]. To assess whether the observed reduction in GLT-induced apoptosis in EZH2 KDs was associated with reduced activation of the ER stress pathway, we thus investigated different targets of the unfolded protein response at different time points by qPCR. We observed a protection against GLT-induced upregulation of Activating transcription factor 4 (Atf4) and Spliced X-box-binding protein-1 (sXbp1) mRNA expression in EZH2 KD cell lines sh3 and sh 4 after 24 h exposure (Figure 3A,B), suggesting downregulation of Protein kinase RNA-like endoplasmic reticulum kinase (PERK) and Serine/threonine-protein kinase/endoribonuclease (IRE1) pathways, respectively. Binding immunoglobulin protein (Bip) mRNA expression, a target gene of Activating transcription factor 6 (ATF6), did not change significantly between EZH2 KDs or empty vector (ev) with the exception of sh4 after $24 \mathrm{~h}$ GLT-exposure, suggesting that the ATF6 pathway is not the main target of EZH2 (Figure 3C). While we did not see significant reduction of Chop mRNA in EZH2 KDs (Figure 3D), we did observe protection against GLT-induced upregulation of Chop protein in sh3 and sh4 (Figure 3E). Of note, Chop expression did not change significantly in sh1 compared to ev (Figure 3E), mirroring the lack of protection against GLT-induced apoptosis for this cell line (Figure 2C). Thus, we conclude that moderate EZH2 attenuation modestly protects the $\beta$-cell against GLT-induced activation of ER stress pathways.

\subsection{EZH2 Attenuation Does Not Protect against GLT-Induced Insulin-Secretory Dysfunction}

Several studies have shown that homozygous conditional $\beta$-cell EZH2 deficiency in RIP-Cre;Ezh2fff or Pdx1-Cre;Ezh2fff mice leads to impaired glucose-tolerance and insulin secretion $[30,31,33]$. Furthermore, since GLT causes $\beta$-cell secretory dysfunction, we investigated insulin release in GLT-exposed EZH2 KD and HET cells, and in human islets treated with EZH2i. Twenty-four hour insulin release was not altered under normal conditions in EZH2 KD and -HET cells (Figure 4A,B). Only EZH2 HET cells were protected against dysregulated insulin release as assessed by $24 \mathrm{~h}$ accumulated insulin release in response to GLT (Figure 4B). Human islets treated with EZH2i at different concentrations secreted insulin normally in response to glucose (Figure 4C). In GLT conditions, however, EZH2i failed to normalize basal and stimulated insulin secretion (Figure 4C), and insulin content (Figure 4D). This suggests that the rescue potential of HDAC3i on insulin-secretory dysfunction likely targets other factors than EZH2.

\subsection{EZH2 KD Prevents Downregulation of the Non-Canonical NFкB Pathway}

Given the potential link between canonical and non-canonical NFkB activation and ER stress [27-29], and the role of EZH2 as a co-activator of NFKB [26], we aimed to assess the regulation of NFKB in $\beta$-cells exposed to GLT in the absence of EZH2. We used Nuclear factor of kappa light polypeptide gene enhancer in B-cells inhibitor, alpha ( $\mathrm{I} \kappa \mathrm{B} \alpha$ ) and phosphorylated p100 (P-p100) as markers of activation

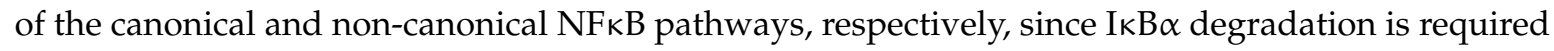
for p65 release and translocation to the nucleus, and since p100 requires phosphorylation in order to be processed to $\mathrm{p} 52$. As expected, we did not observe any changes in IKB $\alpha$ expression in response to GLT, nor did we observe an effect of EZH2 KD (Figure 5A). This strengthens our hypothesis that the canonical NFKB-pathway is not involved in GLT-induced $\beta$-cell apoptosis. 
A

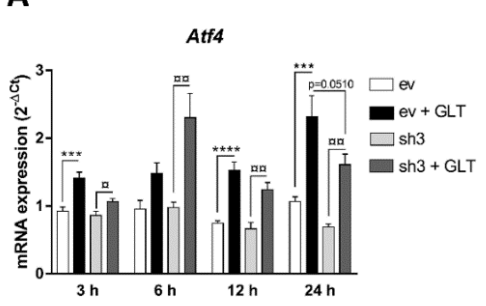

B

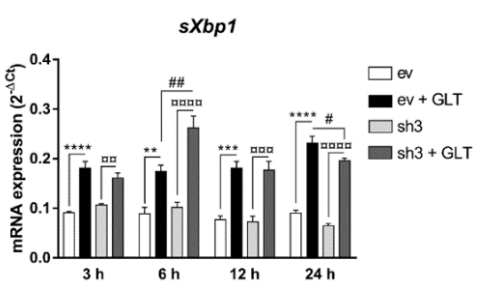

C

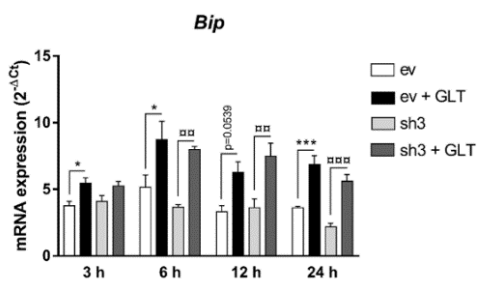

D

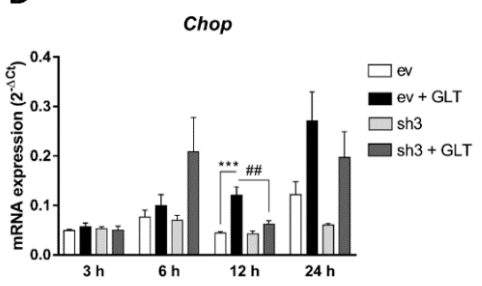

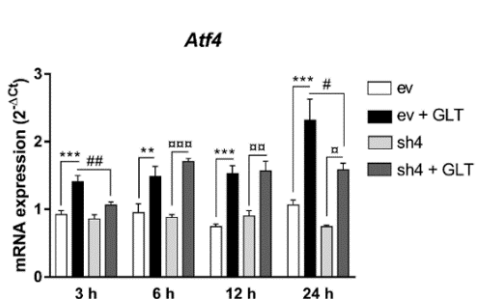

sXbp1

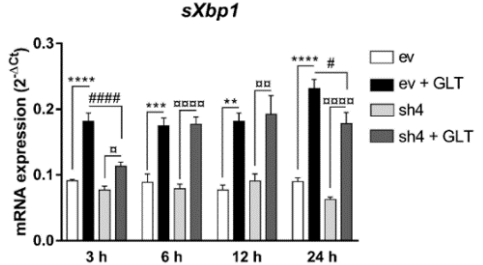

Bip

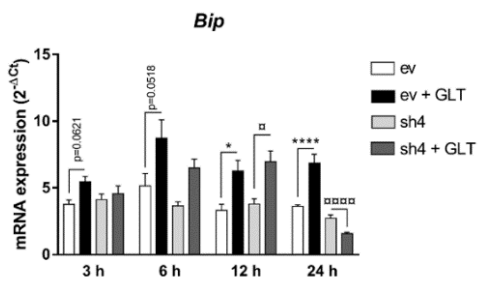

Chop

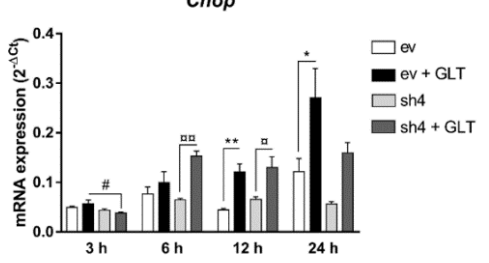

E
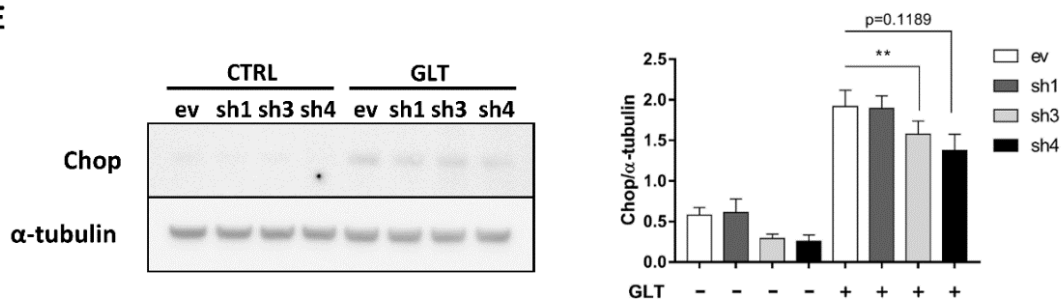

Figure 3. Moderate Enhancer of zeste homolog 2 (EZH2) attenuation protects against glucolipotoxicity (GLT)-induced endoplasmic reticulum (ER) stress. INS-1E cells expressing shRNAs targeting EZH2 (sh3 and -4) were exposed to $25 \mathrm{mmol} / \mathrm{L}$ glucose and $0.5 \mathrm{mmol} / \mathrm{L}$ palmitate (GLT) or vehicle for 3-24 $\mathrm{h}$ (A-D) and mRNA expression of ER stress markers Activating transcription factor 4 (Atf4) (A), Spliced X-box-binding protein-1 (sXbp1) (B), Binding immunoglobulin protein (Bip) (C) and C/EBP homologous protein (Chop) (D) was measured by real-time quantitative PCR. Data presented as means + SEM of $n=5$. (E) INS-1E cells expressing shRNAs targeting EZH2 (sh1, -3 and -4) were exposed to $25 \mathrm{mmol} / \mathrm{L}$ glucose and $0.5 \mathrm{mmol} / \mathrm{L}$ palmitate (GLT) for $24 \mathrm{~h}$ and protein expression of Chop was measured by Western blot. Representative blot of $n=5$. Data presented as means + SEM of $n=5$. ev: INS-1E cells transfected with empty vector; sh1: INS-1E cells transfected with shRNA sequence \#1; sh3: INS-1E cells transfected with shRNA sequence \#3; sh4: INS-1E cells transfected with shRNA sequence \#4. (A-D) analyzed by one-way ANOVA with Sidak's multiple comparisons test. (E) analyzed by paired Student's $t$-test. ${ }^{*} p<0.05,{ }^{* *} p<0.01,{ }^{* * *} p<0.001,{ }^{* * * *} p<0.0001$ ev vs. ev + GLT; ${ }^{a} p<0.05,{ }^{\text {ad }} p<0.01$, ada $p<0.001$, aada $p<0.0001$ sh3 vs. sh3 + GLT (A-D left panels) or sh4 vs. sh4 + GLT (A-D right panels); ${ }^{\#} p<0.05$,

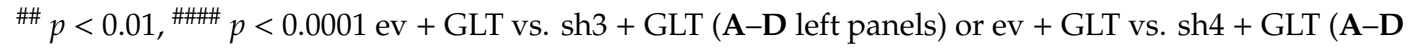
right panels). 
A
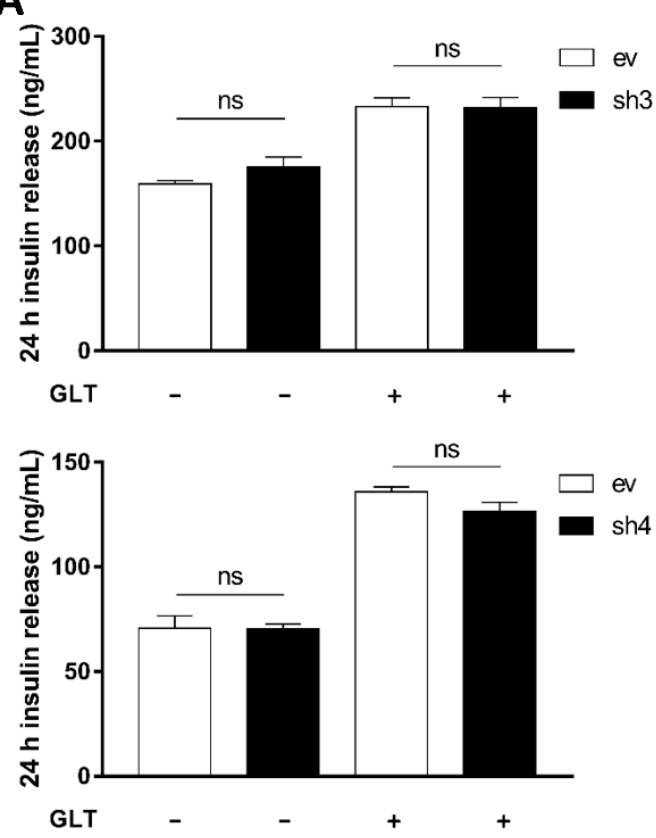

B

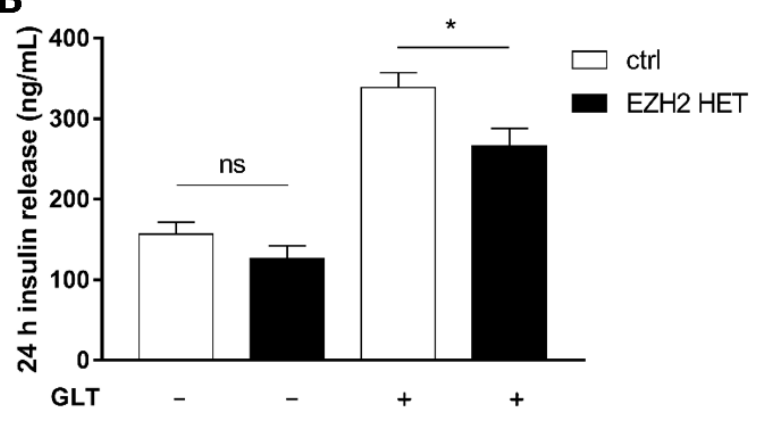

C

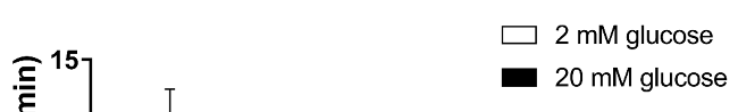

Figure 4. No consistent effect of Enhancer of zeste homolog 2 (EZH2) attenuation on insulin secretion and content under glucolipotoxic (GLT) conditions. Fifty-thousand INS-1E cells expressing shRNAs targeting EZH2 (sh3, upper panel and -4, lower panel; (A)) or gRNA targeting exon 3 of EZH2 (EZH2 HET; (B)) were exposed to $25 \mathrm{mmol} / \mathrm{L}$ glucose and $0.5 \mathrm{mmol} / \mathrm{L}$ palmitate (GLT) for $24 \mathrm{~h}$. Insulin was detected in supernatants by ELISA. Glucose-stimulated insulin secretion (C) and insulin content (D) from twenty human islets exposed to $25 \mathrm{mmol} / \mathrm{L}$ glucose and $0.5 \mathrm{mmol} / \mathrm{L}$ palmitate (GLT) or vehicle in the presence or absence of 0.1-1 $\mu \mathrm{mol} / \mathrm{L}$ EZH2 inhibitor GSK126 or GSK343 for $72 \mathrm{~h}$. Islet donors: 6-10 (Table S2). (A,B) Data presented as means + SEM of $n=4$, analyzed by one-way ANOVA with Sidak's multiple comparisons test. ev: INS-1E cells transfected with empty vector; sh3: INS-1E cells transfected with shRNA sequence \#3; sh4: INS-1E cells transfected with shRNA sequence \#4; ctrl: failed INS-1E CRISPR clone; EZH2 HET: CRISPR/Cas9 modified INS-1E with gRNA targeting EZH2 exon 3. $($ C,D) Data presented as means + SEM of $n=5$. (C) Analyzed by one-way ANOVA with post hoc $t$-test. ns: not significant; ${ }^{*} p<0.05$.

Interestingly, P-p100 was downregulated in ev cells exposed to GLT, suggesting a GLT-induced downregulation of the non-canonical NFkB pathway (Figure 5A). EZH2 KD abrogated GLT-mediated reduction in P-p100 (Figure 5A). Since activation of the p52 subunit can induce anti-apoptotic genes [37], we investigated mRNA expression of the anti-apoptotic p52-target B-cell lymphoma 2 $(B c l 2)$ in mouse islets exposed to GLT and/or EZH2i. Bcl2 was downregulated in GLT-exposed islets, suggesting that a GLT-induced reduction in p52-activation leads to reduced anti-apoptotic $B c l 2$, thereby aggravating apoptosis (Figure 5B). However, we did not observe a rescue potential of $B c l 2$ 
expression in EZH2i-treated islets (Figure 5B), suggesting that other anti-apoptotic p52-targets, such as $B$-cell lymphoma-extra large (Bcl-xL), contribute to protection from GLT-induced apoptosis.

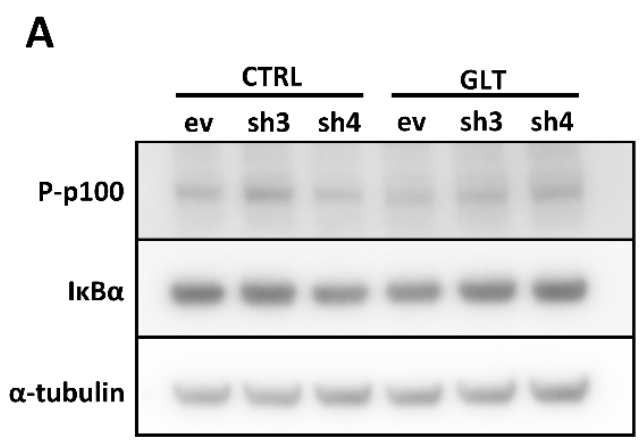

B

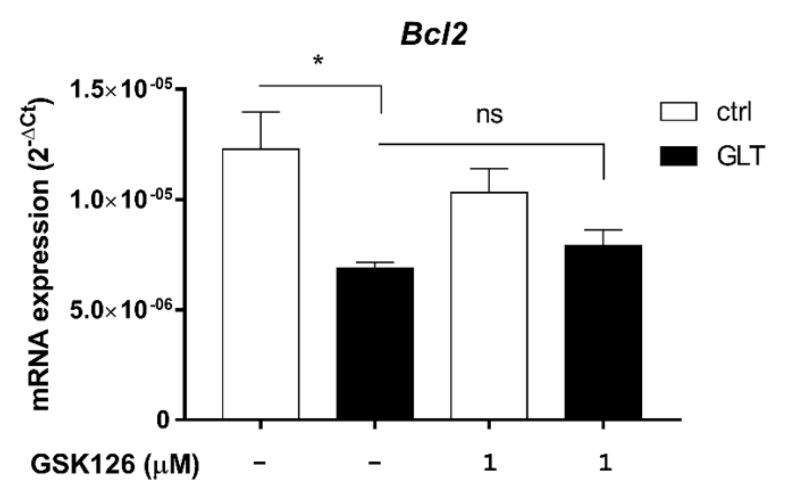

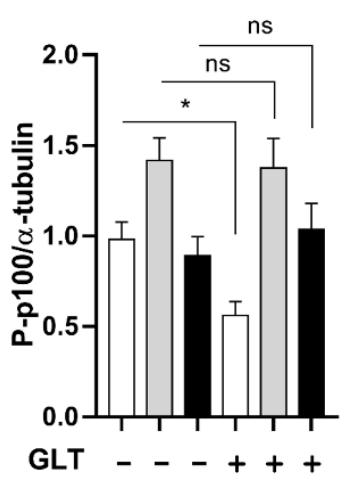

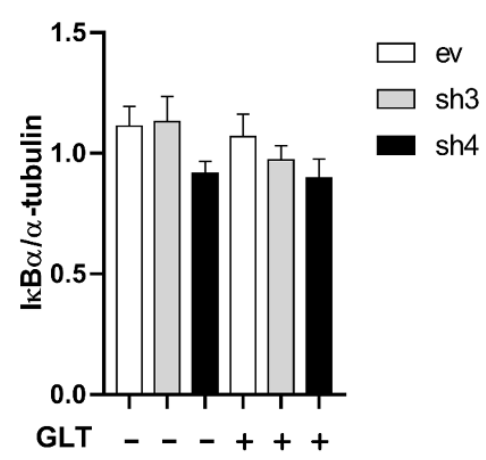

Figure 5. Enhancer of zeste homolog 2 (EZH2) knockdown prevents downregulation of the non-canonical Nuclear factor of kappa light polypeptide gene enhancer in B-cells (NFkB) pathway. (A) INS-1E cells expressing shRNAs targeting EZH2 (sh3 and -4) were exposed to $25 \mathrm{mmol} / \mathrm{L}$ glucose and $0.5 \mathrm{mmol} / \mathrm{L}$ palmitate (GLT) or vehicle (CTRL). Expression levels of phosphorylated p100 (P-p100) and nuclear factor of kappa light polypeptide gene enhancer in B-cells inhibitor, alpha (IкB $\alpha$ ) were detected by Western blot. Data presented as means + SEM. Representative blot of $n=5-7$, analyzed by paired Student's $t$-test. ev: INS-1E cells transfected with empty vector; sh3: INS-1E cells transfected with shRNA sequence \#3; sh4: INS-1E cells transfected with shRNA sequence \#4. (B) One-hundred mouse islets were exposed to $25 \mathrm{mmol} / \mathrm{L}$ glucose and $0.5 \mathrm{mmol} / \mathrm{L}$ palmitate (GLT) or vehicle in the presence or absence of $1 \mu \mathrm{mol} / \mathrm{L}$ EZH2 inhibitor GSK126 for $48 \mathrm{~h}$. B-cell lymphoma 2 (Bcl2) mRNA expression was detected by real-time quantitative PCR. Data presented as means + SEM of $n=3$, analyzed by one-way ANOVA with Sidak's multiple comparisons test. ns: not significant; ${ }^{*} p<0.05$.

\section{Discussion}

In the present study, we aimed to identify novel targets explaining HDAC3i-mediated $\beta$-cell rescue of GLT-exposed insulin-producing cells. We identified the histone/lysine N-methyltransferase EZH2 as a unique chromatin-binding regulator of genes differentially regulated by GLT and HDAC3i. Moderate, but not pronounced, EZH 2 attenuation protected $\beta$-cells and islets against GLT-induced ER stress and apoptosis, likely via regulation of the non-canonical NFKB pathway. To the best of our knowledge, this is the first study describing a role for EZH2 in GLT-induced $\beta$-cell apoptosis.

EZH2 is frequently overexpressed in several cancers, promoting cancer cell-proliferation and -survival. Thus, there is a strong incentive treating cancer patients with EZH2i. Similar to our findings in the $\beta$-cell, higher concentrations of EZH2i or pronounced KD induce apoptosis $[35,36]$ and markers of ER stress [38] in cancer models. Interestingly, evidence from cancer also suggests several EZH2-HDAC3 interaction models. EZH2 stability and HMT activity are examples of phenomena 
regulated by p300/CBP-associated factor (PCAF)-mediated acetylation [39], an acetyl-transferase associated with HDAC3 [40]. Additionally, EZH2 and HDAC3 form a co-repressor complex [41]. Furthermore, combined EZH2/HDAC inhibition synergistically potentiates apoptosis-induction and reduces proliferation [42]. It is worth noting that established anti-proliferative anti-cancer HDACi display anti-inflammatory properties when administered in lower concentrations [43], allowing drug repositioning. This promotes the interesting idea of possible repositioning of low-dose EZH2i, once developed in cancer, for metabolic disease.

The role of EZH2 in the $\beta$-cell has thus far only been investigated with respect to the EZH2 canonical repressive function as the H3K27me3-inducing catalytic subunit of PRC2 [30,31,33], and in this context as a critical regulator during pancreatic endocrine specification [30], and of $\beta$-cell dedifferentiation [31,32] and proliferation [32,33]. However, since EZH2 also displays non-canonical roles, including PCR2-independent EZH2 transcriptional activation [24-26], the differential EZH2 regulated gene expression pattern induced by GLT and HDAC3i suggests that EZH2 differentially regulates its targets by both transcriptional repression and activation. This notion implicates various EZH2-HDAC3 interaction models. Both EZH2 and HDAC3 target lysine 27 (K27) and lysine 4 (K4) on histone $3(\mathrm{H} 3)$ in many regions to regulate transcription (Figure 6A). We observed that EZH2 target genes upregulated by GLT and potentiated by BRD3308 in general possessed functions deleterious to the $\beta$-cell, e.g., Inhibitor of DNA Binding 1 (Id1) and Musashi RNA Binding Protein 2 (Msi2) involved in $\beta$-cell dedifferentiation [44,45], suggesting that BRD3308 failed to counteract this GLT-induced gene expressional response. This notion is compatible with the observation that HDAC1 and $-3 \mathrm{KD}$ protected against cytokine-induced apoptosis, but only HDAC1 KD restored insulin release [46], and that HDAC3i failed to rescue the GLT-induced reduction in insulin stimulatory index [16]. Several genes upregulated by GLT and downregulated by BRD3308 are candidate genes that are deleterious for $\beta$-cells, e.g., Fos Proto-Oncogene (Fos), involved in formation of Activator protein 1 (AP-1) complexes [47], suggesting rescue by BRD3308. We hypothesize that HDAC3 regulates EZH2 HMT activity by EZH2 deacetylation (Figure 6(Ai)) or that EZH2 and HDAC3 function as Co-activators (Figure 6(Aii)) of these genes, and that the observed protective effects of either EZH2i or HDAC3i are a result of disruption of these interactions. This, however, requires experimental validation in our cell model.

Finally, genes downregulated by GLT and upregulated by BRD3308 were generally $\beta$-cell protective candidate genes, including Tumor Necrosis Factor Receptor Superfamily Member $11 b$ (Tnfrsf $11 b$ ). Tnfrsf $11 b$ is involved in protection against inflammatory $\beta$-cell stress [48], and our results thus suggest that BRD3308 rescues GLT-induced downregulation of such protective candidates. We hypothesize that EZH2 and HDAC3 function as co-repressors of these genes (Figure 6(Aiii)), although this also requires experimental validation.

Since homozygous $\beta$-cell EZH2 knockout mice display reduced, while heterozygous knockouts display increased $\beta$-cell mass [30], we aimed at generating homo- and heterozygous clonal EZH2 expressing cell lines to substantiate the observed contrasts in the shRNA knockdowns. While we generated one heterozygous EZH2 expressing cell line, we were unable to generate homozygous knockdowns. Since complete deletion of EZH2 results in embryonic lethality in mice [49], we hypothesize that our inability to generate homozygous EZH2 knockout cell lines from single cells is a result of growth arrest. Taken together with the consistent phenotype observed in our three models of EZH2 deficiency (KD, HET, EZH2i) we suggest that the function of EZH2 in our models primarily ascribes to EZH2 as a PRC2-independent methyltransferase of proteins or a methyl-dependent transcription factor, since the EZH2i employed competitively inhibit the EZH2 catalytic domain by competing for the methyl-donor S-adenosyl methionine (SAM) [50,51].

We conclude from these studies that moderate inhibition of EZH2, a novel target in GLT-stressed $\beta$-cells, protects the $\beta$-cell against GLT-induced ER stress and apoptosis. The protective mechanism involves restoration of the protective non-canonical NFKB pathway (Figure $6 \mathrm{~B}$ ). We also found that EZH2 likely regulates the GLT-HDAC3-apoptosis axis in its capacity as a protein-methyltransferase or methylation-dependent transcriptional activator, but more studies are required to elucidate the 
primary mode of EZH2 function in metabolically stressed $\beta$-cells in vitro and in vivo to assess the translational relevance of targeting EZH2 in T2D.

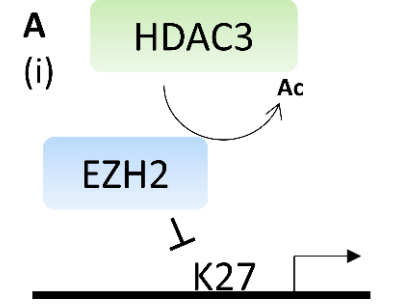

E.g. Rem2, Id1, Fos (ii)

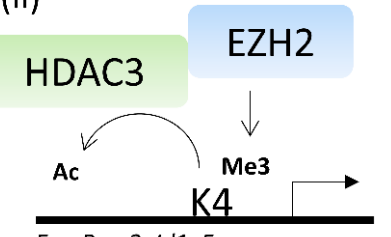

E.g. Rem2, Id1, Fos (iii)

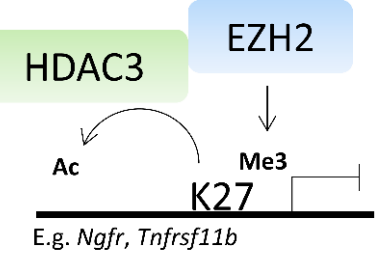

B

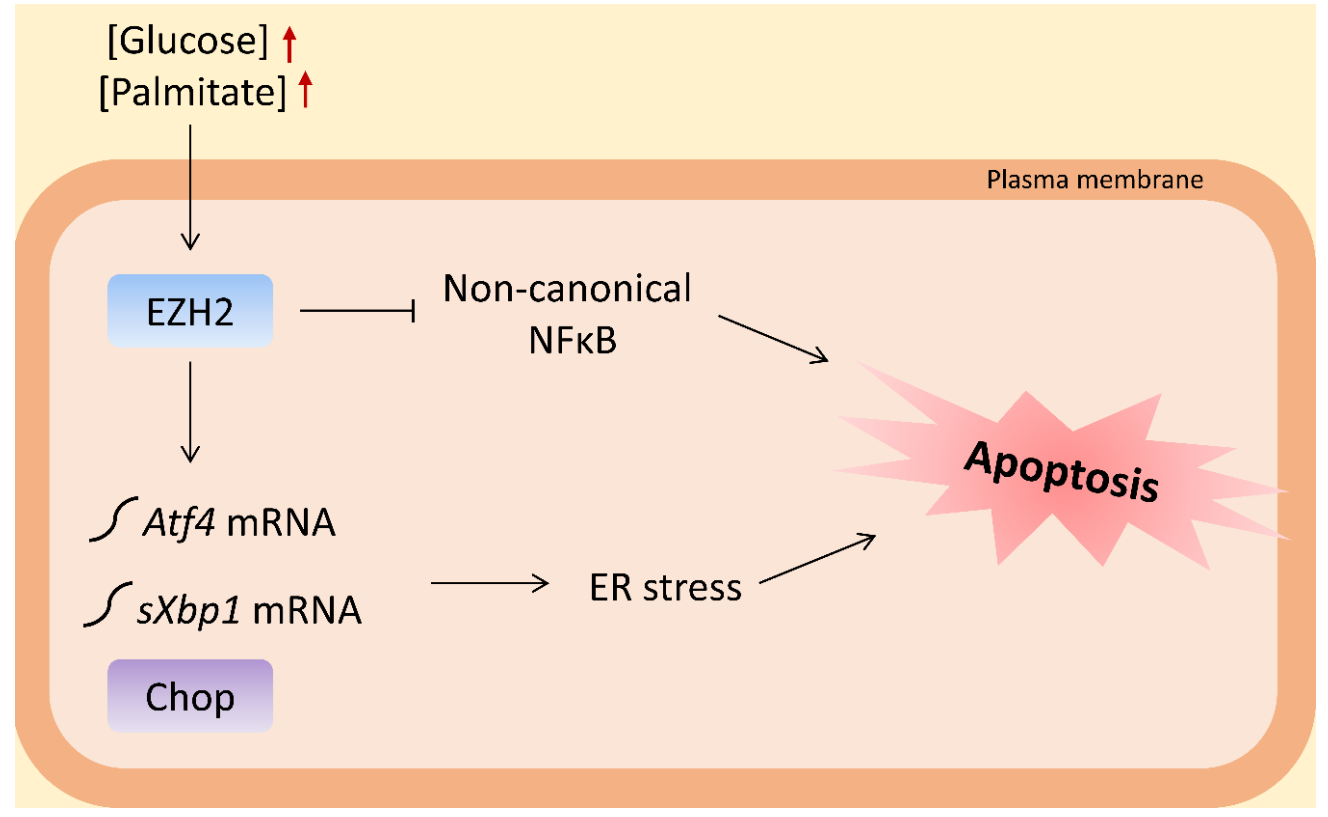

Figure 6. Proposed model of Enhancer of zeste homolog 2 (EZH2)/histone deacetylase 3 (HDAC3) interaction and EZH2 function in the $\beta$-cell. (A) Panel (i): HDAC3 targets EZH2 by removal of the activating acetyl (Ac) mark, leading to reduced EZH2 histone-lysine N-methyltransferase (HMT) activity on histone 3, lysine 27 (H3K27) and increased transcription of deleterious genes. Panel (ii): HDAC3 and EZH2 function as co-activators. HDAC3 catalyzes removal of the histone 3, lysine 4 (H3K4) acetyl-group, leading to EZH2 H3K4 methylation (Me3) and transcriptional activation of deleterious genes. Panel (iii): HDAC3 and EZH2 function as co-repressors. HDAC3 catalyzes the removal of the acetyl-group from H3K27, leading to EZH2 H3K27 methylation and transcriptional repression. (B) Proposed model of EZH2-mediated apoptosis in the $\beta$-cell. Elevated concentrations of glucose and palmitate (GLT) indicated by red arrows induce EZH2-mediated endoplasmic reticulum (ER) stress via increased Activating transcription factor 4 (Atf4) and Spliced X-box-binding protein-1 (sXbp1) mRNA and $\mathrm{C} / \mathrm{EBP}$ homologous protein (Chop) protein expression, and EZH2 potentiates apoptotic signaling by downregulating protective non-canonical Nuclear factor of kappa light polypeptide gene enhancer in B-cells (NFKB) signaling.

\section{Materials and Methods}

\subsection{Cell Culture and Reagents}

INS-1E cells (generated and kindly provided by P. Maechler and C. Wollheim, University of Geneva, Switzerland [52,53]) were cultured in complete RPMI-1640 medium with GlutaMAX (Life Technologies, Naerum, Denmark) supplemented with $10 \%$ fetal bovine serum (FBS) $(v / v), 100 \mathrm{IU} / \mathrm{mL}$ penicillin, $100 \mu \mathrm{g} / \mathrm{mL}$ streptomycin, $10 \mathrm{mmol} / \mathrm{L}$ Hepes, $50 \mu \mathrm{mol} / \mathrm{L} \beta$-mercaptoethanol (all from Life 
Technologies, Naerum, Denmark) and $1 \mathrm{mmol} / \mathrm{L}$ sodium pyruvate (Sigma-Aldrich, Soeborg, Denmark) at $37^{\circ} \mathrm{C}$ in a humidified atmosphere with $5 \% \mathrm{CO}_{2}$. For GLT treatment, culture medium with $1 \% \mathrm{FBS}(v / \mathrm{v})$ and $1 \%$ low endotoxin and fatty acid free BSA (w/v) (Sigma-Aldrich, Soeborg, Denmark) supplemented with $25 \mathrm{mmol} / \mathrm{L}$ glucose and $0.5 \mathrm{mmol} / \mathrm{L}$ ethanol-dissolved palmitate (both from Sigma-Aldrich, Soeborg, Denmark) conjugated to BSA at a molar ratio of 3.33:1 was used. Ethanol and BSA was used as vehicle for GLT. All experiments were performed within the passage numbers $55-80$, since INS-1E display a stable phenotype between passages 40-100 [53]. All cells tested negative for Mycoplasma.

\subsection{Small Molecule Inhibitors}

HDAC3 inhibitor BRD3308 (kindly provided by E. Holson and B. K. Wagner) was dissolved in DMSO (Sigma-Aldrich, Soeborg, Denmark) and used at a concentration of $10 \mu \mathrm{mol} / \mathrm{L}$. EZH2 inhibitors GSK126 (Cayman Chemical, Ann Arbour, MI, USA) and GSK343 (Sigma-Aldrich, Soeborg, Denmark) were dissolved in DMSO (Sigma-Aldrich, Soeborg, Denmark) and used at concentrations of $0.01-10 \mu \mathrm{mol} / \mathrm{L}$. DMSO was used as vehicle in inhibitor experiments, and kept at a concentration $\leq 0.5 \%$.

\subsection{Lentiviral shRNA-Mediated EZH2 Knockdown}

EZH2 knockdown in INS-1E cells was achieved using pLKO.1 Lentiviral shRNA particles (Dharmacon, Herlev, Denmark) against EZH2 mRNA (TRCN0000040073; sh1, TRCN0000039040; sh3, and TRCN0000039041; sh4), pMD2.G (12259) envelope- and psPAX2 (12260) packing-plasmids from the Tronolab (Lausanne, Switzerland) as described in [54]. pLKO.1 empty vector (Sigma-Aldrich, Soeborg, Denmark) was used as control.

\subsection{Generation of CRISPR/Cas9-Mediated Heterozygous EZH2 Expressing Cells}

INS-1E cells genome was modified using ready-to-use Lentiviral particles encoding a guide RNA (gRNA) sequence targeting EZH2 exon 3 (TargetID: RN0000261080) or a non-targeting gRNA (CRISPR12V-1EA) from Sigma-Aldrich, Soeborg, Denmark, as described in [54]. To assess successful gRNA targeting of EZH2, total RNA was isolated from single cell clones and cDNA amplified (details below) using primers binding in the introns flanking the exon of interest (Table S3). PCR product purification and Sanger Sequencing was performed by Genewiz UK (Takeley, UK). Sequences were analyzed and visualized using Unipro UGENE v1.29.0 (Unipro, Novosibirsk, Russia) [55]. Of 20 clonal cell lines, only one displayed modification in EZH2 sequence. Clones with no changes in the target sequence were thus used as controls. Translation of nucleotide to protein sequence was performed using the ExPASY Translate Tool v2 (Swiss Institute of Bioinformatics, Lausanne, Switzerland) [56].

\subsection{Human Islets}

Human islets were isolated by the European Consortium for Islet Transplantation (ECIT) Islets for Basic Research program in Milan, Italy and Geneva, Switzerland under local approval and supported by the JDRF award 31-2008-416. Islets were received fully anonymized, and originated from ten non-diabetic donors (Donor information listed in Table S2). Islets were cultured in RPMI-1640 with a final glucose concentration of $5.6 \mathrm{mmol} / \mathrm{L}$ supplemented with $10 \%$ FBS $(v / v), 100 \mathrm{IU} / \mathrm{mL}$ penicillin and $100 \mu \mathrm{g} / \mathrm{mL}$ streptomycin (all from Life Technologies, Naerum, Denmark), at $37^{\circ} \mathrm{C}$ in a humidified atmosphere with $5 \% \mathrm{CO}_{2}$ for at least 2 days prior to exposure to $0.5 \mathrm{mmol} / \mathrm{L}$ palmitate and $25 \mathrm{mmol} / \mathrm{L}$ glucose in medium with $1 \%$ low endotoxin fatty acid free BSA $(w / v)$ (all from Sigma-Aldrich, Soeborg, Denmark) and without FBS for $72 \mathrm{~h}$.

\subsection{Mouse Islets}

Pancreata were inflated and digested with $1.4 \mathrm{mg} / \mathrm{mL}$ collagenase type 4 (Worthington Biochemical Corporation, Lakewood, CA, USA), and incubated for $30 \mathrm{~min}$ at $37^{\circ} \mathrm{C}$ in a water bath. Islets were filtered, handpicked to purity and cultured at $37^{\circ} \mathrm{C}$ in RPMI-1640 with $11.1 \mathrm{mM}$ glucose supplemented 
with 10\% FBS (v/v), $2 \mathrm{mmol} / \mathrm{L}$ GlutaMAX, $100 \mathrm{IU} / \mathrm{mL}$ penicillin, $100 \mu \mathrm{g} / \mathrm{mL}$ streptomycin and $50 \mu \mathrm{g} / \mathrm{mL}$ gentamycin (all from ThermoScientific, Zug, Switzerland). Islets were exposed to $0.5 \mathrm{mmol} / \mathrm{L}$ palmitate and $25 \mathrm{mmol} / \mathrm{L}$ glucose in medium with $1 \%$ low endotoxin and fatty acid free BSA (w/v) (all from Sigma-Aldrich, Buchs, Switzerland) and 1\% FBS (v/v) for $48 \mathrm{~h}$. All animal experiments were performed according to the Swiss veterinary law and institutional guidelines, and upon approval (accessed on 2 January 2017) by Swiss authorities (Veterinäramt, Basel-Stadt, Switzerland) within the framework of the animal experiment permit 2401.

\section{7. mRNA Microarray}

Total RNA extracted (details below) from INS-1E cells exposed to vehicle or $0.5 \mathrm{mmol} / \mathrm{L}$ palmitate, $25 \mathrm{mmol} / \mathrm{L}$ glucose (all from Sigma-Aldrich, Soeborg, Denmark) and $10 \mu \mathrm{mol} / \mathrm{L}$ BRD3308 (kindly provided by E. Holson and B. K. Wagner) for $6 \mathrm{~h}$ was spotted onto an Affymetrix GeneChip ${ }^{\circledR}$ Rat Genome 230 2.0 Array (ThermoScientific, Copenhagen, Denmark). Microarray data were normalized, analyzed and visualized using R version 3.0.2 (R Foundation for Statistical Computing, Vienna, Austria), Bioconductor v2.12 [57], and the affy v1.38.1 [58], genefilter v1.42.0 [59], annotate v1.38.0 [60], gplots v2.12.1 [61], and rat2302.db v2.9.0 [62] packages. In brief, expressional data were normalized by the Robust Multi-array Average approach, filtered for ENTREZ GENE ID and UNIQUE and assigned Gene Ontology terms for each probe/Affymetrix ID. Next, the top 400 differentially expressed genes were extracted for the two models: ctrl to GLT (disease) and GLT to GLT+BRD3308 (intervention). Genes present in both models were extracted for visualization and for analysis using the ENCODE ChIP-Seq Significance Tool [34]. For visualization relative to the control condition, the control median was subtracted for each gene of interest. Microarray data were validated by real-time PCR (see below).

\subsection{Quantitative Real-Time PCR}

Total RNA was extracted using the NucleoSpin ${ }^{\circledR}$ RNA kit (Macherey-Nagel, Bethlehem, PA, USA), quality and concentration measured on NanoDrop2000 (ThermoScientific, Copenhagen, Denmark), and cDNA synthesized using the iScript ${ }^{\mathrm{TM}} \mathrm{cDNA}$ Synthesis kit (Bio-Rad, Copenhagen, Denmark). cDNA was subjected to qPCR using SYBR Green Master Mix (Applied Biosystems, Naerum, Denmark) and data acquired using the 7900HT Real-Time PCR system (Applied Biosystems, Naerum, Denmark). Primers were purchased from TAG Copenhagen (Copenhagen, Denmark). For primer sequences, see Table S4.

\subsection{Apoptosis}

Fifty thousand INS-1E cells or 25 human islets were plated in duplicates, and apoptosis was determined as accumulation of cytoplasmic histone-associated DNA-fragments using the Cell Death Detection ELISA kit (Roche, Mannheim, Germany) according to the manufacturer's protocol.

\subsection{Immunoblotting}

Two million INS-1E cells were exposed to GLT, lysed in complete lysis buffer ( $50 \mathrm{mmol} / \mathrm{L}$ Tris pH8 (Sigma-Aldrich, Soeborg, Denmark), $150 \mathrm{mmol} / \mathrm{L} \mathrm{NaCl}, 5 \mathrm{mmol} / \mathrm{L} \mathrm{KCl}, 5 \mathrm{mmol} / \mathrm{L} \mathrm{MgCl}_{2}$ (all from Merck, Darmstadt, Germany), 1\% NP-40 (v/v; Sigma-Aldrich, Soeborg, Denmark), 1× Roche protease inhibitors (Roche, Mannheim, Germany) and $20 \mathrm{mmol} / \mathrm{L}$ iodoacetamide (Sigma-Aldrich, Soeborg, Denmark)), and protein concentration was measured using Bio-Rad Protein Assay Dye Reagent (Bio-Rad, Copenhagen, Denmark). Protein concentration-adjusted lysates were loaded onto SDS-PAGE gels as described in [54] and blotted with antibodies against EZH2, Chop, IKB $\alpha$, phosphorylated p100 or $\alpha$-tubulin (Table S5). Blots were developed using chemiluminescence. ImageJ v1.51j8 (NIH, Bethesda, MD, USA) was used for quantification. 


\subsection{Insulin Secretion}

For determination of glucose-stimulated insulin secretion, 20 human islets per well in duplicate were pre-incubated in a 24-well plate in $400 \mu \mathrm{L}$ modified Krebs-Ringer buffer $(115 \mathrm{mmol} / \mathrm{L} \mathrm{NaCl}$, $4.7 \mathrm{mmol} / \mathrm{L} \mathrm{KCl}, 1.2 \mathrm{mmol} / \mathrm{L} \mathrm{KHP}_{2} \mathrm{O}_{4}, 1.2 \mathrm{mmol} / \mathrm{L} \mathrm{MgSO}_{4}, 5 \mathrm{mmol} / \mathrm{L} \mathrm{NaHCO} 3$ (all from Merck, Darmstadt, Germany), $2.6 \mathrm{mmol} / \mathrm{L} \mathrm{CaCl}_{2} \times 2 \mathrm{H}_{2} \mathrm{O}, 0.2 \% \mathrm{BSA}(w / v), 2 \mathrm{mmol} / \mathrm{L}$ glutamine (all from Sigma-Aldrich, Soeborg, Denmark), $20 \mathrm{mmol} / \mathrm{L}$ Hepes (Life Technologies, Naerum, Denmark), $\mathrm{pH}$ adjusted to 7.4; KRBH) supplemented with $2 \mathrm{mmol} / \mathrm{L}$ glucose (Sigma-Aldrich, Soeborg, Denmark) for $1.5 \mathrm{~h}$ at $37^{\circ} \mathrm{C}$ in a humidified atmosphere with $5 \% \mathrm{CO}_{2}$. Islets were subsequently moved to fresh $\mathrm{KRBH}$ supplemented with $2 \mathrm{mmol} / \mathrm{L}$ glucose for $30 \mathrm{~min}$ at $37^{\circ} \mathrm{C}$, followed by collection of $200 \mu \mathrm{L}$ supernatant. Two-hundred $\mu \mathrm{L} \mathrm{KRBH}$ supplemented with $38 \mathrm{mmol} / \mathrm{L}$ glucose were added to wells for a final concentration of $20 \mathrm{mmol} / \mathrm{L}$ glucose for $30 \mathrm{~min}$ at $37^{\circ} \mathrm{C}$. Supernatants were collected and islets were lysed in complete lysis buffer. Twenty-four $\mathrm{h}$ insulin release was measured in supernatants from GLT or vehicle treated INS-1E or EZH2 KD and HET cells. Insulin concentrations of supernatants and lysates were determined using an in-house rat insulin ELISA [63] or Human Insulin ELISA kit (Sigma-Aldrich, Soeborg, Denmark).

\subsection{Data Analysis}

Results are presented as means + SEM. Statistical analyses were performed using GraphPad Prism 8.0 software (San Diego, CA, USA). Student's $t$-test or one-way ANOVA with Sidak's post hoc test were used as indicated to assess statistical significance.

\subsection{Data and Resource Availability}

Datasets generated for this study are available from the corresponding author upon reasonable request.

Supplementary Materials: Supplementary Materials can be found at http://www.mdpi.com/1422-0067/21/21/ 8016/s1.

Author Contributions: Conceptualization, T.D. and T.M.-P.; data curation, T.D. and C.S.; formal analysis, T.D., C.S., M.B.B., M.S.D., M.B.-S., M.T.M., M.L. and T.M.-P.; funding acquisition, T.D. and T.M.-P.; investigation, T.D. and M.L.; methodology, T.D., M.B.B., M.S.D., E.H., B.K.W., M.B.-S., M.T.M., M.L. and T.M.-P.; project administration, T.D.; resources, E.H., B.K.W., M.B.-S. and T.M.-P.; supervision, T.M.-P.; visualization, T.D.; writing一original draft, T.D. and T.M.-P.; writing-review and editing, T.D., C.S., M.B.B., M.S.D., E.H., B.K.W., M.B.-S., M.T.M., M.L. and T.M.-P. All authors have read and agreed to the published version of the manuscript.

Funding: This research was funded by the Danish Diabetes Academy funded by the Novo Nordisk Foundation, the Augustinus Foundation, Fonden til Lægevidenskabens Fremme and the Department of Biomedical Sciences, University of Copenhagen.

Acknowledgments: We greatly appreciate the European Consortium for Islet Transplantation (Milan, Italy and Geneva, Switzerland) for providing human islets. We also thank Claes Wollheim and Pierre Maechler (University Medical Center, Switzerland) for sharing the INS-1E cell line.

Conflicts of Interest: The authors declare no conflict of interest.

\section{Abbreviations}

$\begin{array}{ll}\text { ATF } & \text { Activating transcription factor } \\ \text { Bcl2 } & \text { B-cell lymphoma 2 } \\ \text { Bcl-xL } & \text { B-cell lymphoma-extra large } \\ \text { BiP } & \text { Binding immunoglobulin protein } \\ \text { CHOP } & \text { C/EBP homologous protein } \\ \text { EED } & \text { Embryonic ectoderm development } \\ \text { ER } & \text { Endoplasmic reticulum } \\ \text { EZH2 } & \text { Enhancer of zeste homolog } 2 \\ \text { FOS } & \text { Fos Proto-Oncogene } \\ \text { GLT } & \text { Glucolipotoxicity } \\ \text { HDAC } & \text { Histone deacetylase }\end{array}$




$\begin{array}{ll}\text { HMT } & \text { Histone-lysine N-methyltransferase } \\ \text { ID1 } & \text { Inhibitor of DNA Binding 1 } \\ \text { IKB } \alpha & \text { Nuclear factor of kappa light polypeptide gene enhancer in B-cells inhibitor, alpha } \\ \text { JNK } & \text { c-Jun N-terminal kinase } \\ \text { IRE1 } & \text { Serine/threonine-protein kinase/endoribonuclease } \\ \text { MSI2 } & \text { Musashi RNA Binding Protein } 2 \\ \text { NEFA } & \text { Non-esterified fatty acid } \\ \text { NFkB } & \text { Nuclear factor of kappa light polypeptide gene enhancer in B-cells } \\ \text { PERK } & \text { Protein kinase RNA-like endoplasmic reticulum kinase } \\ \text { PRC2 } & \text { Polycomb repressive complex 2 } \\ \text { RbAp48 } & \text { Histone-Binding Protein Retinoblastoma-Binding Protein } 4 \\ \text { SAM } & \text { S-adenosyl methionine } \\ \text { SUZ12 } & \text { Suppressor of Zeste 12 } \\ \text { T2D } & \text { Type 2 diabetes } \\ \text { TNFRSF11B } & \text { Tumor Necrosis Factor Receptor Superfamily Member 11b } \\ \text { sXBP1 } & \text { Spliced X-box-binding protein-1 }\end{array}$

\section{References}

1. DeFronzo, R.A. Pathogenesis of type 2 diabetes mellitus. Med. Clin. N. Am. 2004, 88, 787-835. [CrossRef] [PubMed]

2. Ling, C.; Groop, L. Epigenetics: A molecular link between environmental factors and type 2 diabetes. Diabetes 2009, 58, 2718-2725. [CrossRef]

3. Maedler, K.; Spinas, G.A.; Dyntar, D.; Moritz, W.; Kaiser, N.; Donath, M.Y. Distinct effects of saturated and monounsaturated fatty acids on beta-cell turnover and function. Diabetes 2001, 50, 69-76. [CrossRef] [PubMed]

4. Cunha, D.A.; Hekerman, P.; Ladriere, L.; Bazarra-Castro, A.; Ortis, F.; Wakeham, M.C.; Moore, F.; Rasschaert, J.; Cardozo, A.K.; Bellomo, E.; et al. Initiation and execution of lipotoxic ER stress in pancreatic beta-cells. J. Cell Sci. 2008, 121, 2308-2318. [CrossRef] [PubMed]

5. Zhou, Y.P.; Grill, V.E. Long-term exposure of rat pancreatic islets to fatty acids inhibits glucose-induced insulin secretion and biosynthesis through a glucose fatty acid cycle. J. Clin. Investig. 1994, 93, 870-876. [CrossRef]

6. Carpentier, A.; Mittelman, S.D.; Lamarche, B.; Bergman, R.N.; Giacca, A.; Lewis, G.F. Acute enhancement of insulin secretion by FFA in humans is lost with prolonged FFA elevation. Am. J. Physiol. 1999, 276, E1055-E1066. [CrossRef]

7. Michaliszyn, S.F.; Bonadonna, R.C.; Sjaarda, L.A.; Lee, S.; Farchoukh, L.; Arslanian, S.A. Beta-Cell lipotoxicity in response to free fatty acid elevation in prepubertal youth: African American versus Caucasian contrast. Diabetes 2013, 62, 2917-2922. [CrossRef]

8. Leahy, J.L.; Cooper, H.E.; Deal, D.A.; Weir, G.C. Chronic hyperglycemia is associated with impaired glucose influence on insulin secretion. A study in normal rats using chronic in vivo glucose infusions. J. Clin. Investig. 1986, 77, 908-915. [CrossRef]

9. Briaud, I.; Rouault, C.; Reach, G.; Poitout, V. Long-term exposure of isolated rat islets of Langerhans to supraphysiologic glucose concentrations decreases insulin mRNA levels. Metab. Clin. Exp. 1999, 48, 319-323. [CrossRef]

10. Federici, M.; Hribal, M.; Perego, L.; Ranalli, M.; Caradonna, Z.; Perego, C.; Usellini, L.; Nano, R.; Bonini, P.; Bertuzzi, F; et al. High glucose causes apoptosis in cultured human pancreatic islets of Langerhans: A potential role for regulation of specific Bcl family genes toward an apoptotic cell death program. Diabetes 2001, 50, 1290-1301. [CrossRef]

11. Malmgren, S.; Spegel, P.; Danielsson, A.P.; Nagorny, C.L.; Andersson, L.E.; Nitert, M.D.; Ridderstrale, M.; Mulder, H.; Ling, C. Coordinate changes in histone modifications, mRNA levels, and metabolite profiles in clonal INS-1 832/13 beta-cells accompany functional adaptations to lipotoxicity. J. Biol. Chem. 2013, 288, 11973-11987. [CrossRef] [PubMed] 
12. Lundby, A.; Lage, K.; Weinert, B.T.; Bekker-Jensen, D.B.; Secher, A.; Skovgaard, T.; Kelstrup, C.D.; Dmytriyev, A.; Choudhary, C.; Lundby, C.; et al. Proteomic analysis of lysine acetylation sites in rat tissues reveals organ specificity and subcellular patterns. Cell Rep. 2012, 2, 419-431. [CrossRef] [PubMed]

13. Mosley, A.L.; Ozcan, S. The pancreatic duodenal homeobox-1 protein (Pdx-1) interacts with histone deacetylases Hdac-1 and Hdac-2 on low levels of glucose. J. Biol. Chem. 2004, 279, 54241-54247. [CrossRef] [PubMed]

14. Christensen, D.P.; Dahllof, M.; Lundh, M.; Rasmussen, D.N.; Nielsen, M.D.; Billestrup, N.; Grunnet, L.G.; Mandrup-Poulsen, T. Histone deacetylase (HDAC) inhibition as a novel treatment for diabetes mellitus. Mol. Med. (Camb. Mass.) 2011, 17, 378-390. [CrossRef] [PubMed]

15. Plaisance, V.; Rolland, L.; Gmyr, V.; Annicotte, J.S.; Kerr-Conte, J.; Pattou, F.; Abderrahmani, A. The class I histone deacetylase inhibitor MS-275 prevents pancreatic beta cell death induced by palmitate. J. Diabetes Res. 2014, 2014, 195739. [CrossRef] [PubMed]

16. Wagner, F.F.; Lundh, M.; Kaya, T.; McCarren, P.; Zhang, Y.L.; Chattopadhyay, S.; Gale, J.P.; Galbo, T.; Fisher, S.L.; Meier, B.C.; et al. An Isochemogenic Set of Inhibitors To Define the Therapeutic Potential of Histone Deacetylases in beta-Cell Protection. ACS Chem. Biol. 2016, 11, 363-374. [CrossRef] [PubMed]

17. Lundh, M.; Galbo, T.; Poulsen, S.S.; Mandrup-Poulsen, T. Histone deacetylase 3 inhibition improves glycaemia and insulin secretion in obese diabetic rats. Diabetes Obes. Metab. 2015, 17, 703-707. [CrossRef]

18. Larsen, L.; Tonnesen, M.; Ronn, S.G.; Storling, J.; Jorgensen, S.; Mascagni, P.; Dinarello, C.A.; Billestrup, N.; Mandrup-Poulsen, T. Inhibition of histone deacetylases prevents cytokine-induced toxicity in beta cells. Diabetologia 2007, 50, 779-789. [CrossRef]

19. Lundh, M.; Christensen, D.P.; Rasmussen, D.N.; Mascagni, P.; Dinarello, C.A.; Billestrup, N.; Grunnet, L.G.; Mandrup-Poulsen, T. Lysine deacetylases are produced in pancreatic beta cells and are differentially regulated by proinflammatory cytokines. Diabetologia 2010, 53, 2569-2578. [CrossRef]

20. Christensen, D.P.; Gysemans, C.; Lundh, M.; Dahllof, M.S.; Noesgaard, D.; Schmidt, S.F.; Mandrup, S.; Birkbak, N.; Workman, C.T.; Piemonti, L.; et al. Lysine deacetylase inhibition prevents diabetes by chromatin-independent immunoregulation and beta-cell protection. Proc. Natl. Acad. Sci. USA 2014, 111, 1055-1059. [CrossRef]

21. Di Croce, L.; Helin, K. Transcriptional regulation by Polycomb group proteins. Nat. Struct. Amp. Mol. Biol. 2013, 20, 1147. [CrossRef]

22. Kim, E.; Kim, M.; Woo, D.H.; Shin, Y.; Shin, J.; Chang, N.; Oh, Y.T.; Kim, H.; Rheey, J.; Nakano, I.; et al. Phosphorylation of EZH2 activates STAT3 signaling via STAT3 methylation and promotes tumorigenicity of glioblastoma stem-like cells. Cancer Cell 2013, 23, 839-852. [CrossRef] [PubMed]

23. Lee, J.M.; Lee, J.S.; Kim, H.; Kim, K.; Park, H.; Kim, J.Y.; Lee, S.H.; Kim, I.S.; Kim, J.; Lee, M.; et al. EZH2 generates a methyl degron that is recognized by the DCAF1/DDB1/CUL4 E3 ubiquitin ligase complex. Mol. Cell 2012, 48, 572-586. [CrossRef] [PubMed]

24. Shi, B.; Liang, J.; Yang, X.; Wang, Y.; Zhao, Y.; Wu, H.; Sun, L.; Zhang, Y.; Chen, Y.; Li, R.; et al. Integration of estrogen and Wnt signaling circuits by the polycomb group protein EZH2 in breast cancer cells. Mol. Cell. Biol. 2007, 27, 5105-5119. [CrossRef]

25. Xu, K.; Wu, Z.J.; Groner, A.C.; He, H.H.; Cai, C.; Lis, R.T.; Wu, X.; Stack, E.C.; Loda, M.; Liu, T.; et al. EZH2 oncogenic activity in castration-resistant prostate cancer cells is Polycomb-independent. Science 2012, 338, 1465-1469. [CrossRef] [PubMed]

26. Lee, S.T.; Li, Z.; Wu, Z.; Aau, M.; Guan, P.; Karuturi, R.K.; Liou, Y.C.; Yu, Q. Context-specific regulation of NF-kappaB target gene expression by EZH2 in breast cancers. Mol. Cell 2011, 43, 798-810. [CrossRef] [PubMed]

27. Hamid, T.; Guo, S.Z.; Kingery, J.R.; Xiang, X.; Dawn, B.; Prabhu, S.D. Cardiomyocyte NF-kappaB p65 promotes adverse remodelling, apoptosis, and endoplasmic reticulum stress in heart failure. Cardiovasc. Res. 2011, 89, 129-138. [CrossRef]

28. Xu, C.; Bailly-Maitre, B.; Reed, J.C. Endoplasmic reticulum stress: Cell life and death decisions. J. Clin. Investig. 2005, 115, 2656-2664. [CrossRef]

29. Shao, C.; Lawrence, M.C.; Cobb, M.H. Regulation of CCAAT/enhancer-binding protein homologous protein (CHOP) expression by interleukin-1 beta in pancreatic beta cells. J. Biol. Chem. 2010, 285, 19710-19719. [CrossRef]

30. Xu, C.R.; Li, L.C.; Donahue, G.; Ying, L.; Zhang, Y.W.; Gadue, P.; Zaret, K.S. Dynamics of genomic H3K27me3 domains and role of EZH2 during pancreatic endocrine specification. Embo J. 2014, 33, 2157-2170. [CrossRef] 
31. Lu, T.T.; Heyne, S.; Dror, E.; Casas, E.; Leonhardt, L.; Boenke, T.; Yang, C.H.; Sagar; Arrigoni, L.; Dalgaard, K.; et al. The Polycomb-Dependent Epigenome Controls beta Cell Dysfunction, Dedifferentiation, and Diabetes. Cell Metab. 2018, 27, 1294-1308.e1297. [CrossRef] [PubMed]

32. Wang, Y.; Sun, J.; Ni, Q.; Nie, A.; Gu, Y.; Wang, S.; Zhang, W.; Ning, G.; Wang, W.; Wang, Q. Dual Effect of Raptor on Neonatal beta-Cell Proliferation and Identity Maintenance. Diabetes 2019, 68, 1950-1964. [CrossRef]

33. Chen, H.; Gu, X.; Su, I.H.; Bottino, R.; Contreras, J.L.; Tarakhovsky, A.; Kim, S.K. Polycomb protein Ezh2 regulates pancreatic beta-cell Ink4a/Arf expression and regeneration in diabetes mellitus. Genes Dev. 2009, 23, 975-985. [CrossRef] [PubMed]

34. Auerbach, R.K.; Chen, B.; Butte, A.J. Relating genes to function: Identifying enriched transcription factors using the ENCODE ChIP-Seq significance tool. Bioinformatics 2013, 29, 1922-1924. [CrossRef]

35. Tan, J.; Yang, X.; Zhuang, L.; Jiang, X.; Chen, W.; Lee, P.L.; Karuturi, R.K.; Tan, P.B.; Liu, E.T.; Yu, Q. Pharmacologic disruption of Polycomb-repressive complex 2-mediated gene repression selectively induces apoptosis in cancer cells. Genes Dev. 2007, 21, 1050-1063. [CrossRef] [PubMed]

36. Wu, Z.L.; Zheng, S.S.; Li, Z.M.; Qiao, Y.Y.; Aau, M.Y.; Yu, Q. Polycomb protein EZH2 regulates E2F1-dependent apoptosis through epigenetically modulating Bim expression. Cell Death Differ. 2010, 17, 801-810. [CrossRef]

37. Viatour, P.; Bentires-Alj, M.; Chariot, A.; Deregowski, V.; de Leval, L.; Merville, M.P.; Bours, V. NF- kappa B2/p100 induces Bcl-2 expression. Leukemia 2003, 17, 1349-1356. [CrossRef]

38. Bujisic, B.; De Gassart, A.; Tallant, R.; Demaria, O.; Zaffalon, L.; Chelbi, S.; Gilliet, M.; Bertoni, F.; Martinon, F. Impairment of both IRE1 expression and XBP1 activation is a hallmark of GCB DLBCL and contributes to tumor growth. Blood 2017, 129, 2420-2428. [CrossRef]

39. Wan, J.; Zhan, J.; Li, S.; Ma, J.; Xu, W.; Liu, C.; Xue, X.; Xie, Y.; Fang, W.; Chin, Y.E.; et al. PCAF-primed EZH2 acetylation regulates its stability and promotes lung adenocarcinoma progression. Nucleic Acids Res. 2015, 43, 3591-3604. [CrossRef]

40. Gregoire, S.; Xiao, L.; Nie, J.; Zhang, X.; Xu, M.; Li, J.; Wong, J.; Seto, E.; Yang, X.J. Histone deacetylase 3 interacts with and deacetylates myocyte enhancer factor 2. Mol. Cell. Biol. 2007, 27, 1280-1295. [CrossRef]

41. Zhang, X.; Zhao, X.; Fiskus, W.; Lin, J.; Lwin, T.; Rao, R.; Zhang, Y.; Chan, J.C.; Fu, K.; Marquez, V.E.; et al. Coordinated silencing of MYC-mediated miR-29 by HDAC3 and EZH2 as a therapeutic target of histone modification in aggressive B-Cell lymphomas. Cancer Cell 2012, 22, 506-523. [CrossRef] [PubMed]

42. Takashina, T.; Kinoshita, I.; Kikuchi, J.; Shimizu, Y.; Sakakibara-Konishi, J.; Oizumi, S.; Nishimura, M.; Dosaka-Akita, H. Combined inhibition of EZH2 and histone deacetylases as a potential epigenetic therapy for non-small-cell lung cancer cells. Cancer Sci. 2016, 107, 955-962. [CrossRef] [PubMed]

43. Dinarello, C.A.; Fossati, G.; Mascagni, P. Histone deacetylase inhibitors for treating a spectrum of diseases not related to cancer. Mol. Med. (Camb. Mass.) 2011, 17, 333-352. [CrossRef]

44. Akerfeldt, M.C.; Laybutt, D.R. Inhibition of Id1 augments insulin secretion and protects against high-fat diet-induced glucose intolerance. Diabetes 2011, 60, 2506-2514. [CrossRef] [PubMed]

45. Szabat, M.; Kalynyak, T.B.; Lim, G.E.; Chu, K.Y.; Yang, Y.H.; Asadi, A.; Gage, B.K.; Ao, Z.; Warnock, G.L.; Piret, J.M.; et al. Musashi expression in beta-cells coordinates insulin expression, apoptosis and proliferation in response to endoplasmic reticulum stress in diabetes. Cell Death Dis. 2011, 2, e232. [CrossRef] [PubMed]

46. Lundh, M.; Christensen, D.P.; Damgaard Nielsen, M.; Richardson, S.J.; Dahllöf, M.S.; Skovgaard, T.; Berthelsen, J.; Dinarello, C.A.; Stevenazzi, A.; Mascagni, P.; et al. Histone deacetylases 1 and 3 but not 2 mediate cytokine-induced beta cell apoptosis in INS-1 cells and dispersed primary islets from rats and are differentially regulated in the islets of type 1 diabetic children. Diabetologia 2012, 55, 2421-2431. [CrossRef] [PubMed]

47. Glauser, D.A.; Brun, T.; Gauthier, B.R.; Schlegel, W. Transcriptional response of pancreatic beta cells to metabolic stimulation: Large scale identification of immediate-early and secondary response genes. BMC Mol. Biol. 2007, 8, 54. [CrossRef]

48. Schrader, J.; Rennekamp, W.; Niebergall, U.; Schoppet, M.; Jahr, H.; Brendel, M.D.; Hörsch, D.; Hofbauer, L.C. Cytokine-induced osteoprotegerin expression protects pancreatic beta cells through p38 mitogen-activated protein kinase signalling against cell death. Diabetologia 2007, 50, 1243-1247. [CrossRef]

49. O'Carroll, D.; Erhardt, S.; Pagani, M.; Barton, S.C.; Surani, M.A.; Jenuwein, T. The polycomb-group gene Ezh2 is required for early mouse development. Mol. Cell. Biol. 2001, 21, 4330-4336. [CrossRef] 
50. McCabe, M.T.; Ott, H.M.; Ganji, G.; Korenchuk, S.; Thompson, C.; Van Aller, G.S.; Liu, Y.; Graves, A.P.; Della Pietra, A., III; Diaz, E.; et al. EZH2 inhibition as a therapeutic strategy for lymphoma with EZH2-activating mutations. Nature 2012, 492, 108-112. [CrossRef]

51. Verma, S.K.; Tian, X.; LaFrance, L.V.; Duquenne, C.; Suarez, D.P.; Newlander, K.A.; Romeril, S.P.; Burgess, J.L.; Grant, S.W.; Brackley, J.A.; et al. Identification of Potent, Selective, Cell-Active Inhibitors of the Histone Lysine Methyltransferase EZH2. ACS Med. Chem. Lett. 2012, 3, 1091-1096. [CrossRef] [PubMed]

52. Janjic, D.; Maechler, P.; Sekine, N.; Bartley, C.; Annen, A.S.; Wolheim, C.B. Free radical modulation of insulin release in INS-1 cells exposed to alloxan. Biochem. Pharmacol. 1999, 57, 639-648. [CrossRef]

53. Merglen, A.; Theander, S.; Rubi, B.; Chaffard, G.; Wollheim, C.B.; Maechler, P. Glucose sensitivity and metabolism-secretion coupling studied during two-year continuous culture in INS-1E insulinoma cells. Endocrinology 2004, 145, 667-678. [CrossRef]

54. Ghiasi, S.M.; Dahlby, T.; Hede Andersen, C.; Haataja, L.; Petersen, S.; Omar-Hmeadi, M.; Yang, M.; Pihl, C.; Bresson, S.E.; Khilji, M.S.; et al. Endoplasmic Reticulum Chaperone Glucose-Regulated Protein 94 Is Essential for Proinsulin Handling. Diabetes 2019, 68, 747-760. [CrossRef] [PubMed]

55. Okonechnikov, K.; Golosova, O.; Fursov, M. Unipro UGENE: A unified bioinformatics toolkit. Bioinformatics 2012, 28, 1166-1167. [CrossRef]

56. Gasteiger, E.; Gattiker, A.; Hoogland, C.; Ivanyi, I.; Appel, R.D.; Bairoch, A. ExPASy: The proteomics server for in-depth protein knowledge and analysis. Nucleic Acids Res. 2003, 31, 3784-3788. [CrossRef] [PubMed]

57. Gentleman, R.C.; Carey, V.J.; Bates, D.M.; Bolstad, B.; Dettling, M.; Dudoit, S.; Ellis, B.; Gautier, L.; Ge, Y.; Gentry, J.; et al. Bioconductor: Open software development for computational biology and bioinformatics. Genome Biol. 2004, 5, R80. [CrossRef]

58. Gautier, L.; Cope, L.; Bolstad, B.M.; Irizarry, R.A. Affy-Analysis of Affymetrix GeneChip data at the probe level. Bioinformatics 2004, 20, 307-315. [CrossRef]

59. Gentleman, R.; Carey, V.; Huber, W.; Hahne, F. Genefilter: Genefilter: Methods for Filtering Genes from High-Throughput Experiments; R Package Version 1.42.0; Bioconductor: Seattle, WA, USA, 2013.

60. Gentleman, R. Annotate: Annotation for Microarrays; R Package Version 1.38.0; Bioconductor: Seattle, WA, USA, 2013.

61. Warnes, G.R.; Bolker, B.; Bonebakker, L.; Gentleman, R.; Liaw, W.H.A.; Lumley, T.; Maechler, M.; Magnusson, A.; Moeller, S.; Schwartz, M.; et al. Gplots: Various R Programming Tools for Plotting Data; R Package Version 2.12.1; Comprehensive R Archive Network: Vienna, Austria, 2013.

62. Carlson, M. Rat2302.db: Affymetrix Rat Genome 2302.0 Array Annotation Data (Chip Rat2302); R Package Version 2.9.0; Bioconductor: Seattle, WA, USA, 2013.

63. Haase, T.N.; Rasmussen, M.; Jaksch, C.A.; Gaarn, L.W.; Petersen, C.K.; Billestrup, N.; Nielsen, J.H. Growth arrest specific protein (GAS) 6: A role in the regulation of proliferation and functional capacity of the perinatal rat beta cell. Diabetologia 2013, 56, 763-773. [CrossRef]

Publisher's Note: MDPI stays neutral with regard to jurisdictional claims in published maps and institutional affiliations.

(C) 2020 by the authors. Licensee MDPI, Basel, Switzerland. This article is an open access article distributed under the terms and conditions of the Creative Commons Attribution (CC BY) license (http://creativecommons.org/licenses/by/4.0/). 